\title{
Report from the NOFOD National Seminar at the CODA International Dance Festival
}

\section{Elizabeth Svarstad}

NOFOD Norway arranged a national seminar for dance researchers and dance artists on October 30, 2021 at the Kristiania University College's Department of Performing Arts in Oslo in cooperation with the CODA Oslo International Dance Festival.

Members of NOFOD and the fields of dance and dance research were invited to present their research. The event was free for all NOFOD members and a fee was required from non-members. In total, 14 persons were present.

Artistic leader and festival director Stine Nilsen opened the seminar by giving a welcome speech.

Invited keynote speaker, Professor Gunn Engelsrud of the Western Norway University of Applied Sciences, Department of Sport, Food and Natural Sciences, gave an enthusiastic and absorbing speech about the state of the art of dance in 2021, throwing light on ongoing debates and freedom of speech from the field of dance's point of view. She presented perspectives on how dance researchers, artists, and teachers can use their voice, trust their position, and

\section{Kari Hoaas}

Photo: Marius Hange

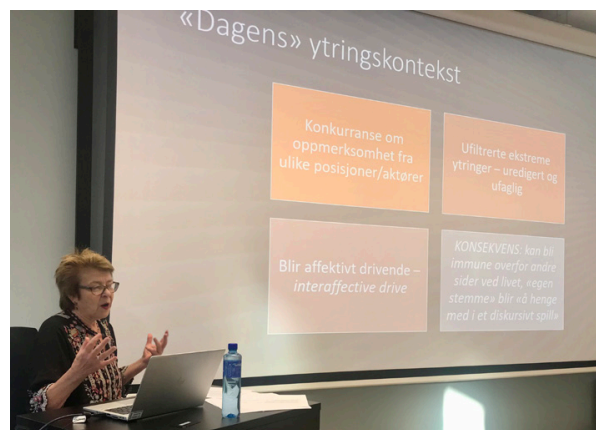

Keynote speaker Gunn Engelsrud. Photo: Elizabeth Svarstad

express themselves in these at-times rough discourses. Engelsrud's keynote speech formed the basis for relevant reflections and good discussion.

Kari Hoaas, a professor in the Department of Performing Arts at Kristiania University College, presented some of her choreographic works from during the lockdowns and restrictions of the pandemic, and provided insight into how the works came about despite limits concerning bodies and space.

Birgitte Kaufmann Olsen, a dance teacher and the director of the dance department at the Trøndertun folk high school (folkehøgskole), gave a presentation of her master's thesis, «The Liberal Learning Potential in dance» [«Dansens dannende potensial»]. Olsen has studied the potential of dance when it comes to education through collected information about students' experiences and her colleagues' didactic reflections. 


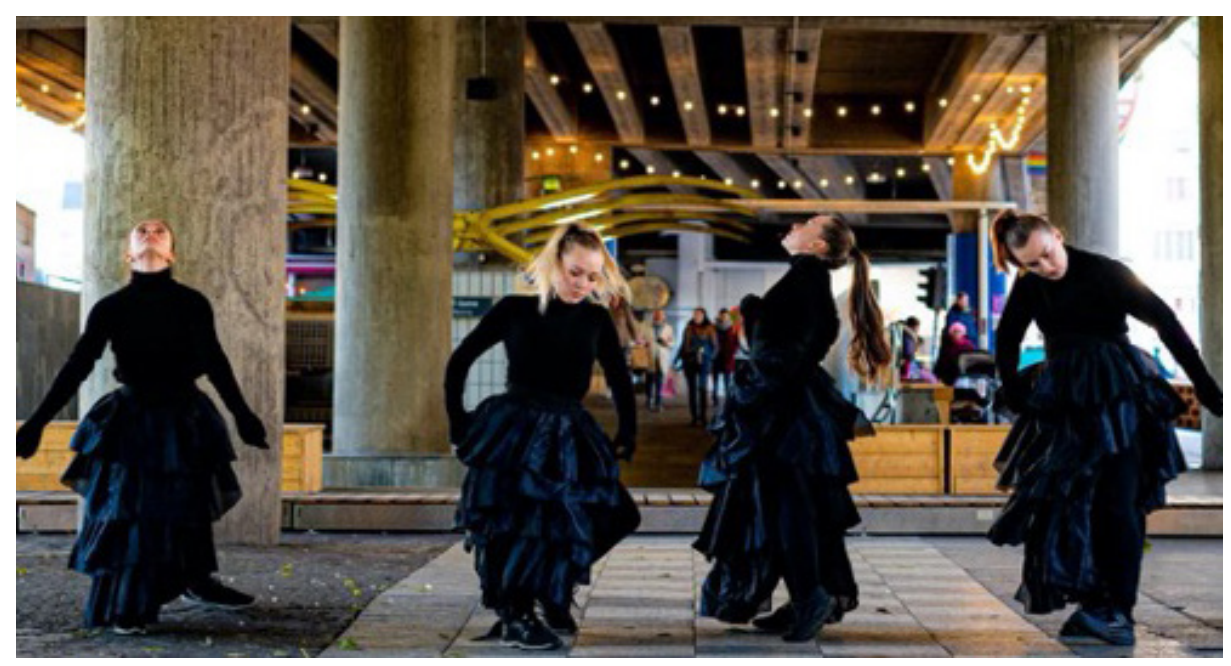

Inés Belli, a dancer and choreographer, presented her master's thesis in art theory from Goldsmiths, University of London. In her thesis she focused on choreography as practice and process as well as the relationship between texts written for choreography and the choreographic practice as an outcome of creating a work based on such writings.

Thomas Talawa Prestø, who is a dancer, the

\section{Thomas Talawa Prestø}

Photo: Elizabeth Svarstad

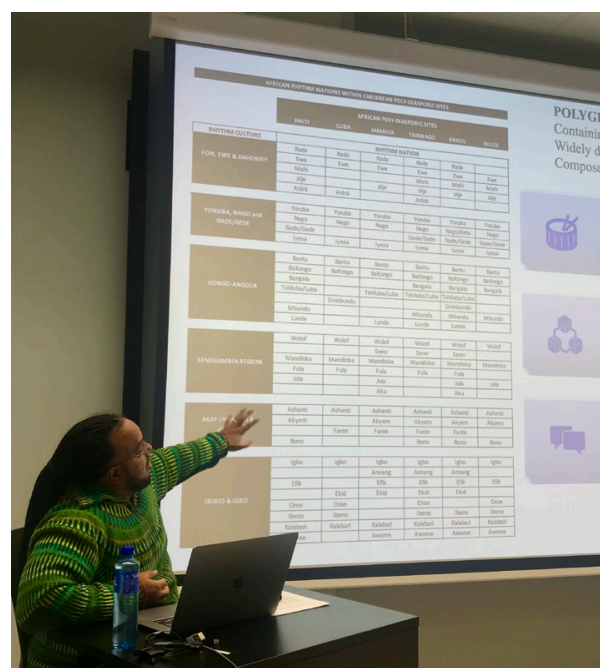

From the performance Mellomrom by Kari Hoaas. Photo: Jonatan Quintero

artistic director of the Tabanka Dance Ensemble and a Ph.D. student at the Østfold University College, presented his work on African art practices and a critical view on how they are appropriated by dance styles such as jazz dance, contemporary dance, hip hop, and even postmodern dance. He also questioned how to decolonise such contexts.

Randi Frønsdal, a dancer, teacher and choreographer, has written a new book on Enrico Cecchetti's method and its importance and influence in classical ballet across the world. Due to health reasons, Frønsdal was not able to attend the seminar herself. Therefore, Elizabeth Svarstad read her paper.

Each presentation was followed by questions from the audience, and there were interesting and engaging discussions shedding light on relevant and important topics within the field of dance research. The organizers, NOFOD board members Irene Velten Rothmund and Elizabeth Svarstad, thank the CODA International Dance Festival and Kristiania University College for their hospitality and cooperation, as well as all of the participants for their valuable contributions. 